\title{
Perbedaan Pemilihan Makanan dan Faktor yang Berkaitan pada Remaja Putri di SMA Daerah Kota dan Kabupaten
}

\author{
Ovi Eka Faradila ${ }^{1}$, Mury Kuswari $^{2}$, Nazhif Gifari ${ }^{3}$ \\ 123Program Studi Gizi, Fakultas Ilmu-ilmu Kesehatan, Universitas Esa Unggul, Jakarta, Indonesia \\ Email: mury@esaunggul.ac.id
}

\begin{abstract}
This study was aimed to analyze differences in food selection and factors related to adolescent girls in the urban and rural high schools. The sampling technique used is the sample size difference of 2 proportions. Data was collected by giving questionnaires to respondents which included food choices and its related factors such as social media, body image, nutritional knowledge, food labels, and peers. Body weight and height used to measure the anthropometric data. The statistical test used in this research was the t-test. There were no differences in food choices, use of social media, perception of actual body shape, perception of desired body shape, and perception of ideal body shape in urban and rural ( $>>0,05)$. There were differences in actual body shape with $B M I$, nutritional knowledge, understanding food labels, and peer influence in rural and urban $(p$ $<0,05)$. Found differences in perceptions of actual body shape with BMI, nutritional knowledge, understanding food labels, and peer influence in urban and rural areas. There were no differences in food choices, but there were differences in factors related.
\end{abstract}

Keywords: Food choices, urban, rural, adolescent girls

\begin{abstract}
Abstrak
Penelitian ini bertujuan untuk menganalisis perbedaan pemilihan makanan dan faktor yang berkaitan pada remaja putri di SMA daerah Kota dan Kabupaten. Penelitian ini menggunakan cross-sectional design. Teknik sampling yang digunakan adalah teknik besar sampel beda 2 proporsi, dengan responden sebanyak 78 siswi pada 2 lokasi penelitian. Pengambilan data dilakukan dengan memberikan angket responden yang meliputi pemilihan makan, media sosial, body image, pengetahuan gizi, label pangan, dan teman sebaya. Pengukuran antropometri dilakukan dengan mengukur berat badan dan tinggi badan. Uji statistik yang digunakan adalah uji beda t-test. Tidak terdapat perbedaan pemilihan makan, penggunaan media sosial, persepsi bentuk tubuh aktual, persepsi bentuk tubuh yang diinginkan, dan persepsi bentuk tubuh ideal di kota dan kabupaten $(\mathrm{p}>0,05)$. Terdapat perbedaan persepsi bentuk tubuh aktual dengan IMT, pengetahuan gizi, pemahaman label pangan, dan pengaruh teman sebaya di kota dan kabupaten $(\mathrm{p}<0,05)$. Tidak terdapat perbedaan pemilihan makan antara remaja putri di kota dan kabupaten, tetapi terdapat perbedaan pada faktor-faktor yang berkaitan dengan pemilihan makan.
\end{abstract}

Kata Kunci: Pemilihan makan, remaja putri, kota, kabupaten 


\section{PENDAHULUAN}

Remaja atau adolescent merupakan periode kritis peralihan dari anak menjadi dewasa. Perubahan hormonal, fisik, psikologis maupun sosial yang berlangsung secara sekuensial terjadi pada masa ini (Batubara, 2010). Peningkatan kebutuhan gizi untuk mendukung pertumbuhan dan perkembangan fisik serta psikis, kebutuhan gizi khusus juga harus diperhatikan terutama pada remaja yang memiliki intensitas aktivitas yang tinggi (Susetyowati, 2017). Kebutuhan gizi dan kesehatan pada masa remaja ini akan mempengaruhi kondisi kesehatan dan status gizi pada masa dewasa. Status gizi pada masa remaja ini dapat dipengaruhi oleh perilaku konsumsi yang meliputi asupan makanan yang dikonsumsi remaja (Adriani and Wirjatmadi, 2012).

Perilaku konsumsi pada remaja mengalami perubahan, baik itu perubahan perilaku konsumsi yang sehat maupun yang tidak sehat. Perubahan perilaku konsumsi dapat mempengaruhi pemilihan makan pada remaja, hal ini yang dapat menyebabkan terjadinya ketidakseimbangan asupan zat gizi pada remaja. Ketidakseimbangan asupan dapat berdampak pada kekurangan atau kelebihan zat gizi. Beberapa studi menunjukkan bahwa pemilihan makan pada remaja dipengaruhi oleh beberapa faktor diantaranya; budaya, akses dan ketersediaan pangan, sosial, orang tua, kepribadian dan sifat, suasana hati dan media (Briawan, Sedayu and Ekayanti, 2011; Hardiansyah, Rimbawan and Ekayanti, 2013)

Media massa atau media sosial memiliki pengaruh untuk mengembangkan motivasi sosial dan keinginan dalam mengonsumsi suatu produk. Remaja yang banyak menghabiskan waktu untuk bermain sosial media serta menonton televisi cenderung akan mengonsumsi makanan yang tidak sehat karena konten atau iklan yang ditampilkan mayoritas mengenai makanan seperti junk food (Aulia \& Yuliati, 2018). Menurut penelitian yang dilakukan oleh Vaterlaus et al., (2015), media sosial juga dikaitkan dengan pemilihan makanan melalui pembuatan beberapa jenis resep, menyediakan tempat untuk menampilkan apa yang dimakan oleh remaja dan persiapannya. Hal ini dapat mengganggu para remaja untuk membuat pemilihan makan yang positif atau sehat. Pada umumnya makanan yang ada di media sosial tersebut adalah makanan yang tidak terlalu memerhatikan kandungan gizinya atau cenderung lebih tinggi kalori, tinggi gula, dan tinggi lemak serta kolestrol (Choudhury, Sharma and Kiciman, 2016).

Aspek lain yang terkait dengan pemilihan makanan remaja adalah kepedulian pada pembacaan label pangan dan gaya hidup. Penelitian yang dilakukan sebelumnya melaporkan bahwa label pangan pada makanan kemasan dapat membantu remaja melakukan pemilihan makan yang sehat (Haidar et al., 2017). Label pangan yang tertera pada kemasan pangan memuat gambaran mengenai isi dan kandungan gizi dari pangan. Informasi tersebut yang dapat dimanfaatkan oleh konsumen untuk memilih pangan kemasan yang sehat (Huda and Andrias, 2016). Ketika seseorang 
memasuki usia remaja, umumnya mereka lebih banyak menghabiskan waktu dengan teman sebaya. Kehadiran teman sebaya tersebut dapat membawa pengaruh dalam pilihan gaya hidup mereka terlebih lagi proses pemilihan makan mereka (Finnerty et al., 2010).

Berdasarkan pemaparan sebelumnya, peneliti mencoba melakukan penelitian untuk membedakan pemilihan makanan remaja yang ada di wilayah perkotaan dan pedesaan, beserta faktor yang terkait dengan pemilihan makanan tersebut. Penelitian sebelumnya telah menjelaskan bahwa gaya hidup dan karakteristik atau kebiasaan remaja yang tinggal di daerah perkotaan (urban) dan pedesaan (rural) tentunya memiliki sebuah perbedaan (Setyawati and Setyowati, 2015).

\section{METODE PENELITIAN}

\section{Desain, Waktu, dan Tempat}

Penelitian ini dilaksanakan di SMA daerah Kota (MA Al-Falah Jakarta) dan SMAN daerah Kabupaten (SMAN 10 Kabupaten Tangerang) pada bulan September - Oktober 2018. Penelitian ini menggunakan cross-sectional design dimana pengambilan data dilakukan dalam waktu yang bersamaan.

\section{Jumlah dan Cara Pengambilan Sampel}

Populasi penelitian ini adalah siswi kelas XI dan XII MA Al-Falah Jakarta dan SMAN 10 Kabupaten Tangerang. Penelitian ini hanya mengambil responden remaja perempuan. Penentuan jumlah sampel dilakukan dengan menggunakan perhitungan sampel beda 2 proporsi dan diperoleh jumlah responden sebanyak 78 siswi dengan 39 siswi disetiap lokasi penelitian.

\section{Pengolahan dan Analisis Data}

Instrumen penelitian yang digunakan pada penelitian ini berupa angket yang meliputi pemilihan makan, media sosial, body image, pengetahuan gizi, label pangan, teman sebaya. Pengukuran antropometri yang dilakukan meliputi berat badan dan tinggi badan. Analisis yang digunakan untuk melihat perbedaan dikedua lokasi menggunakan analisis uji beda $t$-test.

\section{HASIL DAN PEMBAHASAN}

\section{Karakteristik Individu}

Hasil penelitian yang ditunjukkan pada Grafik 1 menunjukkan bahwa siswi paling banyak di kedua lokasi penelitian adalah usia 16 tahun dengan persentase 46,2\% di kota dan 43,6\% di kabupaten. Jumlah siswi paling sedikit ada di usia 18 tahun dengan persentase 2,6\% di kedua lokasi penelitian. 


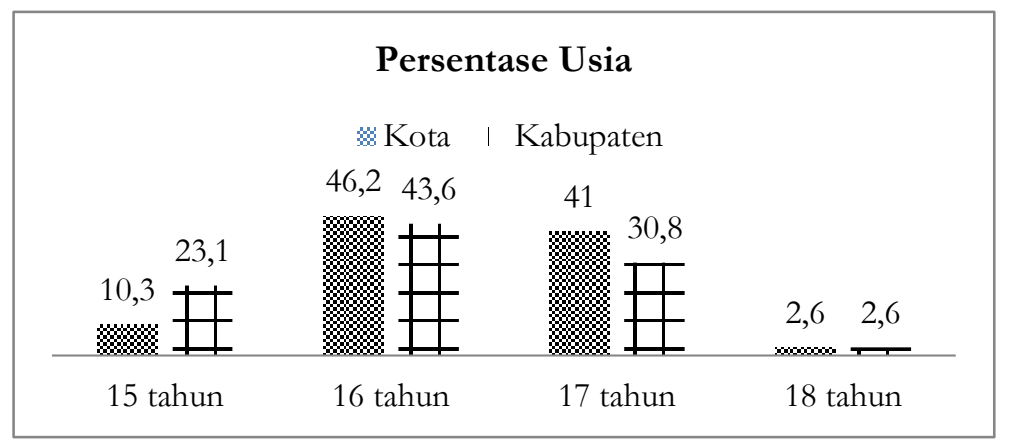

\section{Grafik 1 Distribusi Persentase berdasarkan Usia di Kota dan Kabupaten}

\section{Perbedaan Pemilihan Makan pada Remaja Putri di Kota dan Kabupaten}

Hasil penelitian yang dilakukan menunjukkan bahwa rata-rata skor pemilihan makan di MA Al-Falah sudah baik sedangkan di SMAN 10 hampir mendekati kategori baik. Hal ini diduga karena dari hasil penelitian yang dilakukan dengan menggunakan kuesioner, siswi MA Al-Falah dan SMAN 10 memiliki pemilihan makan yang hampir sama, mereka makan sayur dan buah setidaknya satu porsi setiap harinya dan mereka masih gemar mengonsumsi fast food. Penelitian sebelumnya pada anak Indonesia memberikan gambaran serupa bahwa anak Indonesia kurang konsumsi sayur dan buah serta banyak mengonsumsi fast food, dan kejadian tersebut dapat berlanjut hingga remaja (Hardiansyah, Hardinsyah and Sukandar, 2017). Menurut Abuzaid (2012) di dalam penelitiannya, siswi dari sekolah di perkotaan dan perdesaan (kabupaten) masih gemar fast food, hal ini membuat pemilihan makan pada remaja di perkotaan dan pedesaan cenderung sama.

Tabel 1. Perbedaan Pemilihan Makan dan Faktor yang Berkaitan

\begin{tabular}{|c|c|c|}
\hline Variabel & Mean & Sig. \\
\hline \multicolumn{3}{|l|}{ Perbedaan Pemilihan Makan } \\
\hline Kota & 9,36 & \multirow{2}{*}{0,901} \\
\hline Kabupaten & 9,26 & \\
\hline \multicolumn{3}{|c|}{ Perbedaan Pengunaan Media Sosial } \\
\hline Kota & 41,23 & 0,512 \\
\hline Kabupaten & 40,69 & \\
\hline \multicolumn{3}{|l|}{ Perbedaan Pengetahuan Gizi } \\
\hline Kota & 49,64 & 0,001 \\
\hline Kabupaten & 29,36 & \\
\hline \multicolumn{3}{|l|}{ Perbedaan Label Pangan } \\
\hline Kota & 27,82 & 0,001 \\
\hline Kabupaten & 51,18 & \\
\hline \multicolumn{3}{|c|}{ Perbedaan Pengaruh Teman Sebaya } \\
\hline Kota & 36,26 & 0,001 \\
\hline Kabupaten & 40,77 & \\
\hline
\end{tabular}


Hasil uji beda yang dilakukan dikedua lokasi penelitian menunjukkan bahwa tidak ada perbedaan pemilihan makan yang signifikan di kedua lokasi penelitian. Hal ini diduga karena dari hasil penelitian yang dilakukan dengan menggunakan kuesioner, siswi MA Al-Falah dan SMAN 10 memiliki pemilihan makan yang hampir sama, mereka makan sayur dan buah setidaknya satu porsi setiap harinya dan mereka masih gemar mengonsumsi fast food. Hasil penelitian ini sejalan dengan penelitian yang dilakukan oleh Setyawati \& Setyowati (2015), di Provinsi Jawa Tengah tepatnya di Kota Semarang dan Kabupaten Sragen menunjukkan hasil bahwa tidak ada perbedaan pemilihan makan yang signifikan pada remaja di perkotaan dan perdesaan. Hal ini dikarenakan pemilihan makan pada remaja yang berada di perkotaan dan pedesaan sudah memiliki kesamaan atau tidak ada lagi perbedaan yang terjadi dalam pemilihan makan pada remaja baik di perkotaan maupun di pedesaan.

Penelitian yang di lakukan di perkotaan dan pedesaan ini tidak sejalan dengan penelitian yang dilakukan oleh Baric et al., (2004) yang dilakukan di wilayah perkotaan dan pedesaan di Kroasia yang menunjukan bahwa ada perbedaan yang signifikan pada pemilihan makan di daerah perkotaan dan pedesaan. Perbedaan yang terjadi pada penelitian di Kroasia ini disebabkan karena frekuensi remaja yang konsumsi fast food di perkotaan lebih tinggi dibandingkan dengan remaja di pedesaan.

Hasil pada penelitian ini yang dilakukan di perkotaan dan pedesaan tidak memiliki perbedaan, disebabkan karena pemilihan makan yang diukur menggunakan parameter kuesioner FRS menunjukkan pemilihan yang cenderung sama antara di perkotaan dan pedesaan. Pada penelitian yang dilakukan daerah perkotaan di Afrika oleh Dapi et al., (2005), remaja di perkotaan memiliki kebiasaan makan junk, food yang tinggi atau mereka sering mengonsumsinya, karena makanan tersebut sudah tersedia di berbagai lokasi dan banyak pedagang di sekolah yang menjualnya. Wilayah pedesaan juga memiliki kebiasaan makan junk food sering karena pedagang makanan di sekolah mereka banyak yang menjajakan makanan seperti itu (Bargiota et al., 2013). Hal ini juga terjadi di kedua lokasi penelitan ini, dimana pedagang di masingmasing sekolah banyak yang menjajakan junk food dan sudah tersedianya gerai-gerai fast food di masing-masing lingkungan lokasi penelitian.

\section{Perbedaan Media Sosial pada Remaja Putri di Kota dan Kabupaten}

Hasil penelitian yang dilakukan menunjukkan rata-rata skor penggunaan media sosial di MA Al-Falah baik sedangkan di SMAN 10 termasuk dalam kategori cukup baik dalam penggunaan media sosial di kehidupan sehari-hari mereka. Hal ini disebabkan oleh berkembangnya teknologi khususnya internet di daerah pedesaan. Perkembangan teknologi terutama internet tidak hanya berkembang di daerah 
perkotaan saja tetapi juga merambah ke daerah pedesaan yang digunakan sebagai media untuk berinteraksi, berkomunikasi, dan lain sebagainya

Hasil uji beda yang dilakukan menunjukkan bahwa tidak ada perbedaan penggunaan media sosial yang signifikan di kedua lokasi penelitian. Hal ini terjadi karena akses ke sosial media di kedua lokasi penelitian tidak memiliki perbedaan Penelitian yang dilakukan ini sejalan dengan penelitian yang dilakukan dengan Archana et al., (2017) yang menunjukkan bahwa penggunaan media sosial pada remaja di daerah perkotaan dan pedesaan tidak memiliki perbedaan. Di dalam penelitian ini, hal tersebut disebabkan karena internet khususnya media sosial di perkotaan dan pedesaan sudah berkembang secara pesat. Penelitian ini tidak sejalan dengan penelitian yang dilakukan oleh Prabandari \& Yuliati (2016) yang menyatakan adanya perbedaan penggunaan media sosial pada remaja di perkotaan dan perdesaan. Hal ini disebabkan oleh berbagai faktor, antara lain yaitu durasi penggunaan media sosial pada remaja di perkotaan yang lebih tinggi dibandingkan dengan remaja di pedesaan.

Penggunaan internet atau media sosial di perkotaan dan pedesaan di dalam penelitian ini tidak memiliki perbedaan signifikan. Hal ini disebabkan karena internet di daerah pedesaan tempat penelitian dilaksanakan sudah berkembang dan sudah terbilang cukup bagus untuk pendukung akses ke internet. Pengguna internet atau sosial media di lokasi penelitian di desa juga sudah banyak dan sudah hampir sama dengan penguna sosial media di lokasi penelitian di kota. Siswi di MA Al-Falah Jakarta sudah baik dalam penggunaan internetnya sedangkan siswi di SMAN 10 Kabupaten Tangerang cukup baik dalam menggunakan internet.

\section{Perbedaan Pengetahuan Gizi pada Remaja Putri di Kota dan Kabupaten}

Hasil penelitian yang dilakukan menunjukkan bahwa rata-rata skor pengetahuan gizi di MA Al-Falah dan di SMAN 10 termasuk dalam kategori baik. Hal ini diduga karena di kedua sekolah yang terlibat dalam penelitian ini sudah membahas mengenai gizi dalam salah satu pelajaran mereka, jadi pengetahuan mereka mengenai gizi termasuk kategori baik.

Hasil uji beda yang dilakukan di kedua lokasi penelitian menunjukkan bahwa adanya perbedaan pengetahuan gizi yang signifikan di kedua lokasi penelitian. Hal ini diduga karena di kedua sekolah yang terlibat dalam penelitian ini sudah membahas mengenai gizi dalam salah satu pelajaran mereka, jadi pengetahuan mereka mengenai gizi termasuk kategori baik. Hal ini sejalan dengan penelitian yang dilakukan oleh Ratnaeni (2011) di SMAN 1 Boyolali dan SMAN 1 Cepogo, dimana pengetahuan gizi pada remaja di kedua lokasi penelitian terdapat perbedaan yang signifikan. Meskipun pengetahuan gizi siswi di kedua lokasi penelitian masuk dalam kategori baik, ada perbedaan skor pada kedua lokasi penelitian tersebut. 
Hasil penelitian yang dilakukan tidak sejalan dengan penelitian yang dilakukan oleh Adventiva (2015), dimana hasil penelitian tersebut menunjukkan tidak ada perbedaan yang signifikan antara pengetahuan gizi di perkotaan dan pedesaan. Hal ini dikarenakan di kedua lokasi penelitian mendapat akses mengenai pengetahuan gizi yang sama, sehingga pengetahuan gizi dilokasi penelitian ini hampir sama. Pada penelitian di MA Al-Falah Jakarta dan SMAN 10 Kabupaten Tangerang terdapat perbedaan pengetahuan gizi, meskipun di kedua lokasi penelitian termasuk dalam kategori baik. Perbedaan pengetahuan gizi dikedua lokasi penelitian ini dikarenakan adanya perbedaan skor dikedua lokasi penelitian.

\section{Perbedaan Label Pangan pada Remaja Putri di Kota dan Kabupaten}

Hasil penelitian yang dilakukan menunjukkan bahwa rata-rata skor label pangan di MA Al-Falah dan di SMAN 10 termasuk dalam kategori baik seiring dengan pengetahuan gizi yang baik. Penelitian yang dilakukan oleh Miller \& Cassady (2015) menunjukkan bahwa antara pengetahuan gizi dengan pemahaman mengenai label pangan memiliki hubungan yang signifikan. Jika pengetahuan gizi semakin baik maka semakin baik juga pemahaman mengenai label pangannya.

Hasil uji beda yang dilakukan di kedua lokasi penelitian menunjukkan bahwa ada perbedaan signifikan pemahaman mengenai label pangan di kedua lokasi penelitian. Meskipun skor rata-rata pemahaman menganai label pangan termasuk di dalam kategori baik, terjadi perbedaan pada saat diuji beda. Hal ini disebabkan oleh adanya perbedaan skor rata-rata di kedua lokasi penelitian. Penelitian ini sejalan dengan penelitian yang dilakukan oleh Chopera et al., (2014) di remaja perkotaan dan pedesaan di Zimbabwe, bahwa terdapat perbedaan mengenai pemahaman antara remaja di perkotaan dan pedesaan. Remaja di perkotaan lebih gemar membaca label pangan dan mulai memahaminya dibandingkan dengan remaja di pedesaan.

Penelitian mengenai label pangan di MA Al-Falah Jakarta dan SMAN 10 Kabupaten Tangerang terjadi perbedaan skor rata-rata, dimana skor di SMAN 10 Kabupaten Tangerang lebih tinggi dibandingkan dengan MA Al-Falah Jakarta. Menurut penelitian yang dilakukan oleh Drichoutis et al., (2006), masyarakat di daerah pedesaan lebih cenderung membaca label pangan atau label gizi pada setiap makanan atau minuman. Hal itu membuat mereka lebih sadar akan kebiasaan makan mereka dan paham akan pentingnya label pangan. Penelitian lain yang dilakukan oleh Aygen (2012), masyarakat dipedesaan cenderung lebih sering membaca label pangan dibandingkan dengan masyarakat di perkotaan. Hal ini disebabkan karena masyarakat pedesaaan memiliki aktivitas tidak sepadat dengan masyarakat di perkotaan, yang membuat mereka memiliki waktu untuk mengamati atau memeriksa label pangan ketika membeli makanan atau minuman. 


\section{Perbedaan Teman Sebaya pada Remaja Putri di Kota dan Kabupaten}

Hasil penelitian menunjukkan rata-rata skor pemilihan makan di MA AlFalah cukup berpengaruh sedangkan di SMAN 10 berpengaruh tinggi. Hal ini dikarenakan pada saat diberikan pertanyaan mengenai keputusan membeli jajanan, sebagian besar sampel di kedua lokasi penelitian menjawab setuju apabila teman sebaya mereka memutuskan makanan atau jajanan apa yang akan mereka beli.

Hasil uji beda yang dilakukan di kedua lokasi penelitian menunjukkan bahwa ada perbedaan pengaruh teman sebaya yang signifikan di kedua lokasi penelitian. Hal ini dikarenakan adanya perbedaan rata-rata skor yang dihasilkan. Di MA Al-Falah teman sebaya memiliki pengaruh yang cukup tinggi sedangkan di SMAN 10 memiliki pengaruh yang tinggi. Penelitian yang dilakukan oleh Bargiota et al., (2013) dipedesaan Yunani menyatakan bahwa teman sebaya merupakan salah satu faktor yang berpengaruh dalam pemilihan makan remaja di daerah pedesaan. Remaja menghabiskan setengah hari mereka di sekolah dan membeli makanan ringan bersama teman sebaya mereka yang menjadi acuan penentu makanan apa yang akan dibeli. Penelitian yang dilakukan di perkotaan China oleh Veeck et al., (2014) menyatakan bahwa teman sebaya juga merupakan salah satu faktor yang mempengaruhi proses pemilihan makan pada remaja perkotaan, karena mereka banyak menghabiskan waktu mereka di sekolah dan melakukan kegiatan bersama seperti belajar, bertukar pikiran, dan membeli makanan. Menurut Bargiota et al., (2013), hal ini dikarenakan remaja di pedesaan lebih sering menghabiskan waktunya bersama teman sebaya mereka dibandingkan dengan remaja di perkotaan. Oleh karena itu, teman sebaya di pedesaan memiliki pengaruh yang lebih tinggi dibandingkan dengan teman sebaya di perkotaan.

\section{Perbedaan Body Image pada Remaja Putri di Kota dan Kabupaten}

Hasil penelitian yang dilakukan menunjukkan bahwa rata-rata skor persepsi body image berdasarkan bentuk tubuh aktual di MA Al-Falah sudah baik (masuk kategori normal), persepsi berdasarkan bentuk tubuh yang diinginkan sudah baik (masuk kategori normal) di kedua lokasi penelitian, dan persepsi bentuk tubuh ideal di kedua lokasi penelitian sebagian besar memiliki persepsi tubuh ideal yang positif. Persepsi bentuk tubuh aktual yang dibandingkan dengan status gizi 46,2\% siswi di MA Al-Falah memilih dengan tepat dan 76,9\% siswi di SMAN 10 memilih dengan tepat. Hal ini menunjukkan bahwa siswi di MA Al-Falah belum puas dengan bentuk tubuh mereka, karena 53,8\% siswi menunjukan bahwa bentuk tubuh aktual mereka tidak tepat dengan status gizi mereka. Menurut Septiadewi \& Briawan (2010), remaja merupakan periode dimana terjadinya perubahan bentuk tubuh secara tepat, sehingga membuat remaja merasa tidak puas dengan bentuk tubuh mereka saat ini.

Hasil uji beda yang dilakukan di kedua lokasi penelitian menunjukkan bahwa tidak ada perbedaan persepsi body image berdasarkan bentuk tubuh aktual yang 
signifikan di kedua lokasi penelitian. Persepsi body image berdasarkan bentuk tubuh yang diinginkan tidak ada perbedaan yang signifikan, dan tidak ada perbedaan yang signifikan pada persepsi body image berdasarkan bentuk tubuh ideal di kedua lokasi penelitian. Persepsi bentuk tubuh aktual berdasarkan status gizi memiliki perbedaan yang signifikan di kedua lokasi penelitian.

Tabel 2. Perbedaan Body Image

\begin{tabular}{|c|c|c|c|}
\hline Variabel & Lokasi & Mean & Sig. \\
\hline \multirow{2}{*}{ Persepsi Bentuk Tubuh Aktual } & Kota & 43,67 & \multirow{2}{*}{0,094} \\
\hline & Kabupaten & 35,33 & \\
\hline \multirow{2}{*}{$\begin{array}{c}\text { Persepsi Bentuk Tubuh yang } \\
\text { diinginkan }\end{array}$} & Kota & 38,50 & \multirow{2}{*}{0,652} \\
\hline & Kabupaten & 40,50 & \\
\hline \multirow{2}{*}{ Persepsi Bentuk Tubuh Ideal } & Kota & 40,91 & \multirow{2}{*}{0,534} \\
\hline & Kabupaten & 38,09 & \\
\hline \multirow{2}{*}{$\begin{array}{c}\text { Persepsi Bentuk Tubuh Aktual } \\
\text { dengan IMT }\end{array}$} & Kota & 33,50 & \multirow{2}{*}{0,006} \\
\hline & Kabupaten & 45,50 & \\
\hline
\end{tabular}

Penelitian yang dilakukan oleh Sihag \& Joshi (2017) di India yang melibatkan remaja perempuan dari perkotaan dan pedesaan mengenai kepuasan terhadap bentuk tubuh aktual yang disandingkan dengan status gizi mereka dan menunjukkan hasil bahwa ada perbedaan yang signifikan saat kepuasan terhadap bentuk tubuh aktual disandingkan dengan status gizi remaja perempuan di perkotaan dan pedesaan. Pada penelitian ini yang memiliki ketepatan terhadap bentuk tubuh aktual mereka dibandingkan dengan status gizi diperkotaan sebesar $46 \%$ dan di pedesaan sebesar $76,9 \%$.

Penelitian ini tidak sejalan dengan penelitian yang dilakukan oleh Dev et al., (2009) pada remaja di perkotaan dan pedesaan di Malaysia, dimana tidak ada perbedaan bentuk tubuh aktual saat disandingkan dengan status gizi mereka. Hal ini disebabkan karena status gizi remaja yang ada di perkotaan dan di pedesaan tidak memiliki perbedaan. Pada penelitian yang dilakukan di MA Al-Falah Jakarta dan SMAN 10 Kabupaten Tangerang, persepsi bentuk tubuh aktual siswi di kedua lokasi penelitian ketika dibandingkan dengan status gizi mereka masing masing ada perbedaan, di MA Al-Falah Jakarta siswi lebih banyak yang memilih dengan tidak tepat dan di SMAN 10 Kabupaten Tangerang siswi lebih banyak yang memilih dengan tepat. 


\section{KESIMPULAN}

Tidak terdapat perbedaan pemilihan makan remaja putri di daerah perkotaan dan pedesaan, tetapi terdapat perbedaan pada faktor yang terkait, yaitu persepsi bentuk tubuh berdasarkan status gizi, pengetahuan gizi, pemahaman label pangan, dan pengaruh teman sebaya. Remaja putri di MA Al-Falah Jakarta memiliki rata-rata pemilihan makan yang baik dan disarankan untuk dipertahankan dan jika perlu ditingkatkan. Adapun remaja putri di SMAN 10 Kabupaten Tangerang rata-rata pemilihan makan perlu diperbaiki dan ditingkatkan pemilihan makannya.

\section{DAFTAR PUSTAKA}

Abuzaid, O. I. (2012) Eating patterns and physical activity characteristics among urban and rural students in Saudi Arabia. University of Nebraska.

Adriani, M. and Wirjatmadi, B. (2012) Peranan gizi dalam siklus kehidupan. Jakarta: Prenadamedia Group.

Adventiva, C. (2015) Pengetahuan gizi dan sumber informasinya terhadap status gizi remaja di kota dan di desa. Universitas Gadjah Mada.

Archana, Y. et al. (2017) 'Internet usage of rural and urban adolescents', International Journal of Information Research and Review, 4(4), pp. 3916-3918.

Aygen, F. G. (2012) 'Turkish consumers' understanding and use of nutrition labels on packaged food products', International Journal of Business and Social Science, 3(6), pp. 171-183.

Bargiota, A. et al. (2013) 'Eating habits and factors affecting food choice of adolescents living in rural areas', HORMONES, 12(2), pp. 246-253. doi: 10.14310/horm.2002.1408.

Baric, I. C. et al. (2004) 'Comparison of dietary habits in the urban and rural Croatian schoolchildren', European Journal of Nutrition, 43(3), pp. 169-174. doi: 10.1007/s00394-004-0455-5.

Batubara, J. R. (2010) 'Adolescent development (Perkembangan remaja)', Sari Pediatri, 12(1), pp. 21-29. doi: 10.14238/sp12.1.2010.

Briawan, D., Sedayu, T. R. and Ekayanti, I. (2011) 'Kebiasaan minum dan asupan cairan remaja di perkotaan', Jurnal Giz̨i Klinik Indonesia, 8(1), pp. 36-41. doi: 10.22146/ijen.17729.

Chopera, P., Chagwena, D. and Mushonga, N. (2014) 'Food label reading and understanding in parts of rural and urban Zimbabwe', African Health Sciences, 14(3), pp. 576-584. doi: 10.4314/ahs.v14i3.12.

Choudhury, M. D., Sharma, S. and Kiciman, E. (2016) Characterizing dietary choices, nutrition, and language in foos desserts via social media. San Fransisco: Museums and Public Spaces.

Dapi, L. N. et al. (2005) 'Adolescents' food habits and nutritional status in urban and 
rural areas in Cameroon, Africa', Scandinavian Journal of Nutrition, 49(4), pp. 151-158. doi: 10.1080/11026480500437554.

Dev, O. et al. (2009) 'Rural urban differences in body image perception, body mass index and dieting behaviour among malay adolescent Malaysian schoolgirls', European Journal of Scientific Research, 34(1), pp. 69-82.

Drichoutis, A. C., Lazaridis, P. and Nayga, R. M. (2006) 'Consumers' use of nutritional labels: A review of research studies and issues', Academy of Marketing Science, 10(9), pp. 90-116.

Finnerty, T. et al. (2010) 'Effects of peer influence on dietary intake and physical activity in schoolchildren', Public Health Nutrition, 13(3), pp. 376-383. doi: 10.1017/S1368980009991315.

Haidar, A. et al. (2017) 'Self-reported use of nutrition labels to make food choices is associated with healthier dietary behaviours in adolescents', Public Health Nutrition, 20(13), pp. 2329-2339. doi: 10.1017/S1368980017001252.

Hardiansyah, A., Hardinsyah, H. and Sukandar, D. (2017) 'Kesesuaian Konsumsi Pangan Anak Indonesia Dengan Pedoman Gizi Seimbang', Nutri-Sains: Jurnal Gizi, Pangan dan Aplikasinya, 1(2), p. 35. doi: 10.21580/ns.2017.1.2.2452.

Hardiansyah, A., Rimbawan, R. and Ekayanti, I. (2013) 'Efek Suplementasi Multivitamin Mineral Terhadap Kadar Hemoglobin Dan Hematokrit Mahasiswi Tpb Ipb', Jurnal Gizi dan Pangan, 8(1), p. 47. doi: 10.25182/jgp.2013.8.1.47-54.

Huda, Q. A. and Andrias, D. R. (2016) 'Sikap dan perilaku membaca informasi gizi pada label pangan serta pemilihan pangan kemasan', Media Gizi Indonesia, 11(2), pp. 175-181. doi: 10.20473/mgi.v11i2.175-181.

Miller, L. M. S. and Cassady, D. L. (2015) 'The effects of nutrition knowledge on food label use. A review of the literature', Appetite, 92, pp. 207-216. doi: 10.1016/j.appet.2015.05.029.

Prabandari, K. and Yuliati, L. N. (2016) 'The influence of social media use and parenting style on teenagers' academic motivation and academic achievement', Journal of Child Development Studies, 1(1), pp. 40-54. doi: 10.29244/jcds.1.01.39-53.

Ratnaeni, I. M. (2011) Perbedaan pengetabuan gizi dan status gizi pada remaja di sma kota dan desa Studi di SMAN 1 Boyolali dan SMA N 1 Cepogo). Universitas Muhammadiyah Surakarta.

Septiadewi, D. and Briawan, D. (2010) 'Penggunaan metode Body Shape Questionnaire (SSQ) dan Figure Rating Scale (FRS) untuk pengukuran persepsi tusuh remaja perempuan', Gizi Indonesia, 33(1), pp. 29-36.

Setyawati, V. A. V. and Setyowati, M. (2015) 'Karakter gizi remaja putri urban dan rural di provinsi Jawa Tengah', Jurnal Kesehatan Masyarakat, 11(1), p. 43. doi: 10.15294/kemas.v11i1.3463. 
Sihag, R. and Joshi, H. (2017) 'A study on body image satisfaction, BMI status and dietary patterns among newly entrant girl students of Punjab Institute of Medical Sciences, Jalandhar', International Journal Of Community Medicine And Public Health, 4(7), pp. 2531-2537. doi: 10.18203/2394-6040.ijcmph20172854.

Susetyowati (2017) Ilmu gizi teori dan aplikasi; Giz̨i remaja. Jakarta: Buku Kedokteran EGC.

Vaterlaus, J. M. et al. (2015) 'The perceived influence of social media on young adult health behaviors', Computers in Human Behavior, 45, pp. 151-157. doi: 10.1016/j.chb.2014.12.013.

Veeck, A. et al. (2014) 'Influences on food choices of urban Chinese teenagers', Young Consumers, 15(4), pp. 296-311. doi: 10.1108/YC-08-2013-00390. 